\title{
EU challenges, investment in the EU and the role of the European Investment Group
}

DEBORA REVOLTELLA, Ph.D.*

Conference keynote**

https://doi.org.10.3326/pse.41.1.2

\footnotetext{
* This keynote speech largely relies on the publication of EIB (2016) and Revoltella (2016).

${ }^{* *}$ Received: January 13, 2017

Accepted: February 7, 2017
}

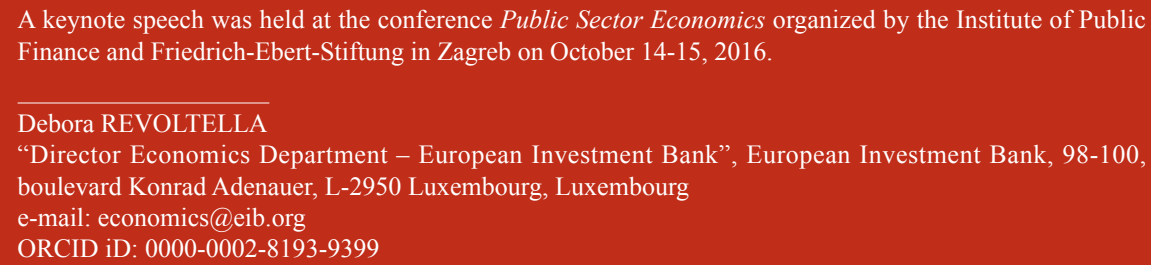

"Director Economics Department - European Investment Bank", European Investment Bank, 98-100, boulevard Konrad Adenauer, L-2950 Luxembourg, Luxembourg e-mail: economics@eib.org ORCID iD: 0000-0002-8193-9399 
Since the financial crisis, Europe has made tremendous progress. Countries have adjusted macroeconomic policies and implemented structural reforms, while economic policy co-ordination has been strengthened. A modest economic recovery is underway, but uncertainty is high and productivity growth and competitiveness are still weak, affecting the medium-term growth outlook.

Following the recession triggered by the sovereign debt crisis, the recovery began in most EU member states in early 2013. It started as an export-driven upswing but has been increasingly supported by domestic demand, particularly consumption. Growth of domestic demand has been sustained by falling oil prices and overall inflation, as well as by a very accommodating monetary policy and the phasing-out of fiscal retrenchment.

Against this backdrop, and when compared with past recoveries, this rally is disappointing. It also appears vulnerable given the downside risks and limited policy space. While monetary policy is close to the limits of what it can achieve, consensus on a more active fiscal policy is still lacking.

Indeed, on the political front, Europe stands at something of a crossroads, facing growing social, economic and political challenges. Efforts are now focused on pragmatically advancing on key common priorities. The urgency and ambition with which this cooperation proceeds will be critical to success.

\section{FROM INVESTMENT CRISIS TO SUB-OPTIMAL INVESTMENT RECOVERY?}

The recovery of investment has been even slower than that of overall output. EU investment growth in the last three years has been $3.1 \%$ per year, slightly below the pre-crisis average rate of $3.4 \%$ and well below historical rates of investment growth during recoveries from financial crises.

There are also large differences in regional and sectoral investment performance. By mid-2016, investment in the less crisis-hit "old" member states (hereafter "core countries") had reached the pre-crisis level. However, investment in the mostly "new" member states or "cohesion countries" was still 9\% below, and in the most crisis-hit "vulnerable countries" still $27 \%$ below the pre-crisis level.

In terms of asset composition, expenditure on machinery and equipment and intellectual property is leading the investment recovery, with gaps versus pre-crisis real investment levels still visible in cohesion and vulnerable countries. Construction, both residential and non-residential, remains depressed overall: investment in new construction exceeds pre-crisis levels in only five member states, while in 15 it is more than $15 \%$ below pre-crisis levels.

The gradual recovery of investment is good news, but there are downside risks. Falling productivity growth, comparatively low levels of investment in intangible 
capital and falling investment in infrastructure pose a threat to future growth. Financing conditions for firms have improved, but the risk of systemic market failures has not disappeared.

In particular, revised data show that infrastructure investment is falling. The introduction of the ESA 2010 national accounting categories has enabled a much more accurate estimation of infrastructure investment in Europe. We now see that infrastructure investment, previously thought to have been quite resilient, has fallen by about one quarter, from $2.3 \%$ to $1.7 \%$ of GDP, since 2009 . By 2015 it was well under 2005 levels, with no sign of a turnaround.

While corporate infrastructure investment fell at the start of the crisis, public infrastructure investment accounts for most of the decline since then. As mentioned, fiscal consolidation has been the main driver. While the ratio of government investment to GDP is close to its long-term average, this is not true for government investment in infrastructure: in this case the gap remains. It is clear that fiscal consolidation has played a restraining role, particularly in vulnerable countries, and most EU governments did not plan increases in government investment in 2016 and 2017.

At the EU level, corporate investment has been the main driver of the slow investment recovery. It has reached the pre-crisis peak in core countries, but not in the vulnerable or cohesion group, with low investment in buildings and structures providing the main drag. The ratio of corporate investment to GDP in 2015 is below its 1999-2005 average, and accounts for a quarter of the decline in the total investment to GDP ratio since that period. Thus, while corporate investment is indeed driving the mild investment recovery, it remains weak by historical comparison.

Our estimations show that the average realised internal rate of return of firms has been in decline since the beginning of the financial crisis, across countries, sectors and firm sizes. Such a decline is to be expected after a crisis, but after eight years this explanation becomes less plausible, and it becomes increasingly likely that the decline is driven by falling rates of productivity growth. While easy monetary policy may have cushioned this trend, its continuation would obviously have serious implications for investment and potential growth.

Productivity-enhancing investment in intangible capital has been resilient, but lags global peers. In the EU, investment in intellectual property rights, a large part of which is accounted for by R\&D expenditures, has fared better than investment in tangible capital, with levels now higher than those before the crisis (Greece, Latvia and Romania are notable exceptions). Yet global comparisons are not so flattering. The ratio of R\&D expenditures to GDP in the EU remains nearly 1 percentage point below the US level, and is more and more lagging behind the rapid growth in China, Japan and South Korea. EU investment in the broader category of intangible assets has proved resilient, but is significantly lower than in 
the US, with growth too slow to close the gap. Investment in intangibles is positively correlated with greater labour market flexibility and government investment in R\&D.

Financial conditions for firms have improved, but there remains room for further action. The ECB and other European central banks have reacted to the crisis with an extraordinary package of monetary easing, including lowering interest rates to their effective lower bound and introducing unconventional measures such as asset purchase programmes. At the same time, the banking union aims to improve the resilience of the banking sector. These measures have gone a long way towards normalising financial conditions for investment by firms. Notably, the process of financial market fragmentation is gradually being reversed, particularly in the sense that spreads in bond yields and corporate lending rates between core and vulnerable countries have narrowed. In addition, bank lending is gradually increasing and access to external finance in general is improving, supported by an extremely accommodative monetary policy. So far, this has considerably compensated for the falling returns on investment in the post-crisis period.

However, many firms still face financing constraints, and given the possibility of a continued low interest rate environment with declining productivity growth and limited scope for further monetary easing, some areas of weakness are troubling. First, despite the positive results of the 2016 European Banking Association stress tests and the magnitude of the regulatory adjustment achieved, there has been no confidence rally, and European banks continue to suffer from very low valuations. Full recovery may require structural changes in the business model of some banks. Second, despite the monetary policy-driven compression of bond yield spreads within the euro area, cross-border capital flows, particularly to cohesion countries, remain well below their pre-crisis levels, and such capital flows have been one of the key drivers of convergence in the EU. Third, SMEs continue to face higher lending rates and are more likely to perceive their financial situation as constrained. Access to equity for SMEs remains difficult, with private equity volumes still well below pre-crisis levels and the venture capital segment still very dependent on government support.

The impact of the crisis on the financial system has had knock-on effects on firm productivity growth. Our analysis shows that the crisis has reduced the ability of the EU financial system to allocate resources efficiently to support the most productive firms, thereby contributing to slowing productivity growth overall. Firms in the EU have been particularly exposed to the effects of the crisis because of their heavy reliance on bank lending and lack of opportunities to turn to capital markets. We find that firms that use more equity, retained earnings and trade credit have tended to achieve improved investment and sales, both before and after the crisis, whereas highly leveraged firms have tended to experience the opposite. The credit-supply shock generated by the financial crisis has also meant that the allocation of bank credit between firms has been determined to a lesser extent by their 
productivity and growth potential, and more by their size or the balance sheet health of their main bank. Credit supply to smaller firms fell more, and these firms had more difficulties compensating for reduced external financing with other sources of finance. Our research suggests that firms in sectors with a high growth potential have been particularly adversely affected.

Against this backdrop, public policies to address market failures and frictions and to enhance productivity growth remain critical. Avoiding investment stagnation requires continued action on at least three fronts: structural reforms focused on market flexibility to support innovation and productivity growth; financial sector reforms to further improve banking sector resilience and develop capital markets as an alternative source of finance; and public support for investment, making the best use of available EU and national financing capacities to address investment gaps in infrastructure and innovation, and to help alleviate the financial constraints faced by smaller firms.

A remaining competitiveness gap suggests room for policy action on investment. Years of underinvestment, exacerbated by the crisis, mean that many infrastructure assets are reaching the end of their economic life, creating an investment backlog. At the same time, infrastructure needs to be upgraded to meet the emands of the future, such as the need to ensure the security and sustainability of energy supply, to ensure efficient and sustainable mobility and logistics, to meet demand for digital services and to remain resilient to the effects of climate change and resource scarcity. Annual investment shortfalls include:

- EUR 100 billion to upgrade energy networks in a way that would allow the integration of renewable energy sources, and thereby improve efficiency and ensure security of supply;

- EUR 80 billion to upgrade transport networks with the aim of reducing congestion costs and trade bottlenecks;

- EUR 65 billion to reach the EU's Digital Agenda standards in broadband, data centre capacity, and cyber security;

- EUR 10 billion for state-of-the-art education facilities, in addition to EUR 90 billion in increased operational spending, so as to reach US standards, mostly in higher education;

- EUR 90 billion to rehabilitate environmental services and ensure water security in the face of climate change;

- EUR 130 billion a year in R\&D to meet the EU target of 3\% of GDP.

\section{ROLE OF THE EUROPEAN INVESTMENT BANK}

Against this backdrop, the EIB has a unique role to play in supporting investment in Europe. In particular, the EIB plays an important catalytic role in promoting sound investment projects in support of EU policy goals in Europe and beyond. As a bank, it raises money from international capital markets, using its AAA credit rating (graph 1). As a public institution owned by the 28 member states of the EU, it lends them funds to finance investment projects that address systemic 
market failures or financial frictions, targeting four priority areas in support of growth and job creation: innovation and skills, SMEs, climate action and strategic infrastructure.

In 2015, the EIB provided EUR 77.5 billion in long-term finance to support private and public productive investment, of which the European Investment Fund (EIF) provided EUR 7 billion. At a first estimate, this helped realise investment projects worth roughly EUR 230 billion and EUR 27 billion, respectively. All the projects the EIB finances must not only be guaranteed to bring a profit but also to comply with strict economic, technical, environmental and social standards in order to yield tangible results in improving people's lives.

Alongside lending, the EIB's "blending" activities can help leverage available funding by, for example, helping transform EU resources under the European Structural and Investment Funds (ESIF) into financial products such as loans, guarantees, equity and other risk-bearing mechanisms. Advisory activities and technical assistance can help projects to get off the ground and maximise the value-for-money of investments.

EIB lending has a big impact: during the last capital increase period (2013-2015) EIB total lending supported EUR 372 billion of investment. Our preliminary estimates suggest that this may increase the EU's GDP by around $1.1 \%$ by 2030 , adding about 1.4 million jobs.

\section{Graph 1}

The role of the EIB Group

EIB Group

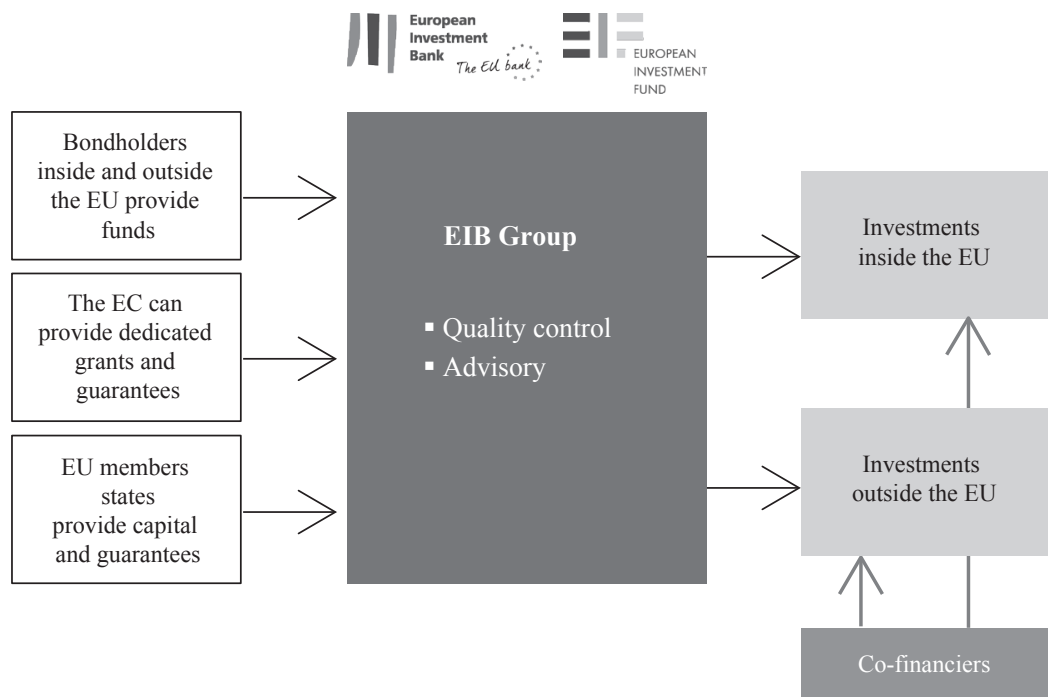


The Investment Plan for Europe (the so-called "Juncker Plan"), undertaken by the European Commission and the EIB, further enhances the EU policy response to re-launch investment and restore EU competitiveness. It consists of three main pillars: finance through the European Fund for Strategic Investments (EFSI) to enhance the EIB Group's capacity to address market failures in risk-taking that hold back investment; the European Investment Advisory Hub (EIAH) to provide comprehensive technical assistance in the sourcing, preparation and development of investment projects; and support for regulatory and structural reform to remove bottlenecks and ensure an investment-friendly environment. As of mid-October 2016, 362 EFSI transactions were approved, potentially leveraging $44 \%$ of the full EUR 315 billion envisaged.

\section{CONCLUSION}

Investment in the EU has started to recover, but this recovery is weak by historical comparison and uneven across countries and sectors. Declining investment in infrastructure is a major concern, with implications for Europe's long-term competitiveness and potential growth. Slow recovery of corporate investment is equally disturbing, particularly given the extraordinary monetary stimulus provided by the ECB and other European central banks. The persistent decline in rates of return on corporate investment suggests that action is needed to raise productivity growth. Yet innovation-related investment in intangibles remains low by international standards, and binding financial constraints and other market failures have reduced the efficiency of resource allocation. Against this backdrop, the EIB is in a unique position to help overcome these market failures and help restart the investment cycle in Europe. In 2015 alone, the EIB provided close to EUR 80 billion in long-term finance to support private and public investment worth an estimated EUR 260 billion. This catalytic role of the EIB may be often underappreciated by the general public, but is well-known among official EU and member country institutions, and is likely to increase further with implementation of the Investment Plan for Europe. 
1. EIB, 2016. Investment and Investment Finance in Europe - Financing productivity growth. Luxembourg: European Investment Bank.

2. Revoltella, D., 2016. EU Challenges, Investment in the EU and the Role of the European Investment Group. Intereconomics, 51, p. 331. doi: 10.1007/s10272016-0630-y 